\title{
Empowering the Abused Souls in No Tengas Miedo (Don't be Afraid)
}

\author{
Pogkrong Boon-Long
}

\begin{abstract}
Musically talented Silvia, the female protagonist of the 2011 Spanish film, No Tengas Miedo (Don't Be Afraid), was delicately and powerfully portrayed as a young woman who had been sexually abused by her father since she was a little girl. Through dramatic plot and storyline, the film creator presented the remarkable process of healing which was employed by Silvia, and it naturally provided a chance for the audiences to experience the protagonist's sufferings in her severely wounded soul and/or healed themselves along with her. This paper means to analyze such a process presented in the film which has high capability to heal and empower the sexual abused, including the author, who examines this representation. The crucial findings from the process are creating the sincere community for the abused to share their anxieties and sufferings, and encouraging them to accept and face their fears.
\end{abstract}

Index Terms-Empowerment, female representation, healing process, child sexual abuse.

\section{INTRODUCTION}

The European Union Film Festival was officially held for the first time in Thailand at Bangkok in late 1980s. Throughout the years, various kinds of films have been elaborately selected from the EU country members. Besides promoting EU nations and film industry, the festival gives native and foreign audiences in Thailand chances to enjoy the contents of those films and at the same time learn about European cultures and people. As an admirer of the festival, I attended almost every time it was held. Many films shown in the festival offered me inspiration and provided me chances to learn and explore some particular issues which captured my attention for some time. In May 2013 festival which was held in Bangkok downtown, and moved up northeastern Khon Kaen, then up north to Chiang Mai, I, as a graduate in the field of women's studies and also a survivor of sexual abuse in late teenage, have found that the Spanish film, No Tengas Miedo [1] or Don't Be Afraid in English version, directed by Montxo Armendariz, provide its audiences' space for healing themselves from being victims of childhood sexual abuse in an impressive manner. The film presents a practical method of healing such experiences which leads to empowering those who were sexually abused in their childhood. Moreover, it gives advices to the society to prevent and protect children from this type of domestic threat.

No Tengas Miedo, as a representation, presents the story of

Manuscript received January 1, 2014; revised March 11, 2014

Pogkrong Boon-Long is with the College of Interdisciplinary Studies, Thammasat University, Bangkok, Thailand (e-mail: dmtu1234@yahoo.co.th).
Silvia, an early 20-year-old girl who had been sexually abused by her father since she was in primary school. During those time, she had sensed her physical pain and initially reconsidered that experience through role-playing with her puppets. Silvia's mother witnessed such activity of her daughter and was also told about her husband's behavior from Silvia's own mouth, but decided not to believe any of it. In addition, she reprimanded Silvia for telling what she considered to be nonsensical. Silvia had been living her life being sexually abused until she reached puberty. She was a talented amateur cellist and eagerly wanted to further her study on music composition in another city, which led to her father's disapproval. That issue, along with Silvia's problem in excretory system, caused by being sexually abused for years, and also the separation of her parents, resulting in leaving Silvia with her father, made Silvia feel like being a sex object of her father, who is a professional dentist Consequently, Silvia was driven to break away from her father's cage. In the process of breaking away, Silvia had a car accident, but fortunately her condition was not severe, and she got kind help from Dr. Hidalgo, a delicate psychiatrist working at the hospital where Silvia was admitted. Dr. Hidalgo led Silvia through the healing process in the community of the survivors who experienced child sexual abuse.

\section{Female Representation In Child SeXual Abuse PLOT ON CONTEMPORARY CINEMA SCREEN IN BANGKOK}

In contemporary Bangkok, only a few films which have female protagonists in the plot of child sexual harassment performed by parents are allowed to be shown. One of them, Polisse [2], a French film shown at a downtown art-house cinema in Bangkok in early 2013, presents a story of a police squad in charge of guarding youth safety. Many cases of child sexual abuse appear in the film, but are roughly detailed. This film significantly portrays the squad members' daily routines and obstacles in life and work. A lot of child characters, especially girls, who were sexually abused in many of those cases, are presented as pitiful, and in many ways onerous to the whole society. Sexual complexes of those child characters are limitedly discussed and given any advice on.

The plot of parents performing sexual abuse, especially towards girls, is considered a taboo in Thai cinema. Chued-Gorn-Chim (The Butcher) [3], a Thai film released in 2009, portrays a female protagonist who was sexually harassed when she was a young girl, then was raped by two male characters, who were ambiguously presented as her father and elder brother, and got pregnant in teenhood. In the 
film's end credit, which the specific statuses of those two male characters are listed, the audiences would be informedthat both men were in fact the protagonist's stepfather and stepbrother. The people who made harassment to the young female character in this film were men who had no biological bonds with her. That can be considered a compromise between the critical chance for the creator of Chued-Gorn-Chim to contribute his work publicly and the myth in Thai society about the paternal role as a child's fosterer and protector. Anyway, this particular myth is obviously challenged in another controversial Thai thriller, Chuan (Slice) [4], which was released in the same year. The young male protagonist of this film was violently tortured by his biological father, who, in one of the film's most vulgar scenes, performed a savage sodomy with him when he was a weak young child in a rustically domestic area. These two depressing representations depict sexual violence on children in contemporary Thai cinema. What makes them more depressing is that the two protagonists, in the portrayals of a cruelly psychotic female murderer who made a living by selling noodles with full-flavored meat soup and a ruthless serial killer who professed as a glamorous transfemale entertainer respectively, are presented to be uncontrollably dangerous and in the end must be eliminated by the law.

Silvia, as a female representation in No Tengas Miedo, was created, in the same way as the protagonists of the two aforementioned films, through the process of selection, arrangement and accentuation, along with the construction of meanings and values [5], by the film creator. What makes this female representation far different from those in the local releases, who were harassed by their close family members, is her status as a survivor who was able to heal her own self from the traumatic experience on sexual abuse in her childhood, and was able to overcome her anguish and confusion with essential help from great strength and encouragement. In addition, the character showed that she had a potential of assisting others who had suffered from similar incidents of domestic violence.

\section{LOCATING THE FEAR}

Abuse, as Kate Ollier and Angela Hobday [6] pointed out, was the condition about inequality of power in various areas, including age, bodily size, and intellectual ability. Abuse is conducted without informed and mutual consent. The abused with little life experiences, such as children, are mostly considered the ones who lack capability to comprehend should they be informed about their abused conditions [6]. Generally, adults who perform abusive acts hold dominant roles. Ann Cattanach [7 ] notified that sexual abuse was an act of forcing or enticing a child to take part in a sexual activity, and she added that children who were sexually abused "suffer some form of emotional abuse because they are disempowered by the adult involved. [7]" Silvia, the protagonist of No Tengas Miedo, struggled with the torture mainly caused by her abusive father for years. During such crisis, Silvia was forced to take the inferior silenced role, which was partly an effect of her mother's ignorance on the truth about abusive acts selfishly done by her father.

By the notion about four fundamental forms of child abuse, which, according to Swea Jelic Tuscic, Gordana Buljan Flander and Dragana Mateskovic [8], are coined as physical abuse, emotional abuse, sexual abuse, and neglect, Silvia is considered a victim of abuse in all those forms on account of both her parents. In the context of No Tengas Miedo storyline, the sexual abuse performed by Silvia's father was the main cause which, as a relevant consequence, brought about the other three forms of child abuse, and it drove the abused girl to live her life in the agony of great pain. At the age of 6 , little Silvia played a tickle game with her father on the sofa in their apartment. He made his daughter, who at that time innocently and trustfully joined the abusive game, lie face down on a sofa, then performed some sexual activity on the low back part of her body, an act which partly implied sodomy. Silvia grown up and, to her mother's ignorance, was sexually abused frequently by her father. Silvia's mother considered a dialogue Silvia came up in a role-play with her puppets, which connoted the oral sex experience with her father, and also the girl's testimony on it just a dumb wandering thought. That was the beginning of merciless ignorance Silvia received from her mother, and it made her feel sad, lonely and insecure. Such an act naturally put Silvia in a state of being emotionally abused. Since then, Silvia's mother left her, a little girl then, to cope with the sexual abuse by her father alone. That could be considered a kind of neglect. Though living under the same roof with her parents, Silvia was neglected by both of them. Throughout teenhood years, Silvia could not tell anyone, even Maite, her only close friend, or even her mother who moved out to live with her new husband, about her depressing situation. Long-time sexual abuse performed by Silvia's father awfully affected her physical health, which naturally led to her mental health. Because of the frequent sexual act which implied sodomy, Silvia in her teenage had a problem in excretory system. In a film sequence, while Silvia had given money to a vender in the community's Sunday market to buy a bottle of nail varnish, which, in this context, signifies her pubertal interest in self-beauty, she abruptly made a pause to the purchase and took a very quick walk, in a terribly controlled manner, to the public restroom, then came back pitifully to finish buying the cosmetics.

The relationship between Silvia and her father, who for years had her, from a very little girl to a young lady, sexually abused, and made her bear with it as a common thing in her everyday life at home, carried on as an incest. The violence from sexual abuse created by Silvia's father in the context of incest, hence, caused sufferings mingled with love and affection [9] to her. When teenage Silvia luckily met Dr. Hidalgo, a skillful and caring psychiatrist, she bitterly confessed to her that she had struggled with her mixed feelings between love and hatred towards her father. Silvia's hatred on her father obviously erupted in her teenage when he did not allow her to further her study on music composition in another city. For Silvia, that meant he cut off the chance for her to develop her talent on music, one of a few faiths upon which she could rely in her gloomy life, a creative skill she practiced together with Maite, and, certainly, a seemingly only chance for her to break away from his abusive embrace. Since then, Silvia realized that her father was in fact a very selfish man who had been treating her as his property. That is 
the notion which many men claim as a rights for them to have their own daughter sexually abused [10], [11]. After the separation of Silvia's parents, she was bound more tightly to the status of daughter and wife of her father. Being possessed and limited in the freedom of living her own life, especially in making progress in music study, pushed confused Silvia to break off the incest, but, at the same time, her tremendous fear of accepting the strongly combined feelings between love and hatred towards her father held her back from stepping over the frame of bitter relationship which she had been familiar with almost her entire life.

In the storyline of No Tengas Miedo, the film creator impliedly suggested that, for the abused, locating the fear caused by being sexually abused could be taken as the beginning of a healing process. Such a suggestion reflects on the situation when Silvia firstly met Dr. Hidalgo, who appeared to be a maternal figure to her, at a hospital after Silvia's car accident. Silvia avoided seeing her father who meant to take her home, and she got a practical help from the brilliant psychiatrist. After that Dr. Hidalgo warm-heartedly asked Silvia about the cause of her sufferings. At that moment Silvia did not answer her directly, and, instead, repressively told her in tears about the great pain of the symptom in her abdomen. Such an answer of Silvia implied her investigation on the cause of fear she was facing, and her untold great shame and sufferings from being abused by her father via her talk about that great pain in her body which naturally connected with her deepest soul. Dr. Hidalgo was the first person outside Silvia's family who was aware of her great trauma, and sincerely cared for her feeling towards the awful situation. Silvia's impression on Dr. Hidalgo brought about her trust on the generous psychiatrist, whose kind support for the protagonist in this context conforms with what Daniel J. Schober, Stephen B. Fawcett and Jetta Bernier [12] noted that social communities and social institutes, including members and authorities of those social units, were supposed to take important roles on decreasing and eliminating sexual abuse, and giving all possible supports to the abused.

\section{BODY AS A HEALING TOOL}

Playing cello as a hobby, Silvia used music as a channel for relieving her painful feelings and comforting her soul. However, despite living her life with this favorite hobby, Silvia was controlled purposefully by her parents over the chance to further her music study, and unintentionally by Maite, her long-time buddy at school, who did not have an inkling of Silvia's trauma and made a blame on Silvia's sudden change of producing the melody of classical pieces by her beloved cello, from the gloomy one of Falla, while playing in harmony with Maite's piano, to the merry one of Bach. That sudden change made by Silvia can be considered an expression of the abused in order to release some part of her repressed trauma and break the silence [13]. Inevitably, Silvia was bound with sufferings caused by her intimate people. Every time Silvia went out of her father's apartment to hang out and spend personal time at her favorite noisy game room, she carried her beloved cello with her without playing it. The cello in this context signifies Silvia's encouragement and shelter where she could make a temporary escape from the painful reality. In the end of the film, when Silvia gained her self confidence and eliminated her fear of the things which caused her trauma, she decided to move out of her father's apartment and leave the cello in the living room.

Cattanach [14] also instructed that "The abused child is the invisible child", and Silvia had been pushed into such condition for many years before entering the healing process implemented by Dr. Hidalgo. That condition occurred to the protagonist because of her accumulated sufferings from the long-term sexual abuse. Silvia could not tell anybody else about the incident. She grew up silent and cheerless. The invisible condition in Silvia's life was directly related to her sense of self. Silvia's childhood was lost and she was forced to bear the abuse repeatedly happened in her daily life. It went without saying that Silvia's father stole her childhood. The restriction on studying music composition in another city was the main force which pushed Silvia to search for the life out of her father's cage. Silvia's need to live freely drove her into taking reactions to her father on making a claim for her existence as an individual, and also her own rights to determine a way of living.

Furthermore, Cattanach [14] noticed that the two major ways for the abused child to become visible were to disappear, or to make the loudest noise as possible. For Silvia, she chose the former option by once vanishing from home while her father was in his dental clinic hours. At that time, absent-minded Silvia, who stayed in her subconscious and temporarily secluded herself from the outside world, unexpectedly opened the passenger door of the cab she briefly engaged in after a group of merry family, and threw herself out of the moving car without any sense of caring for the foreseen danger at hand. Then Silvia was sent to the hospital and got Dr. Hidalgo's care. Silvia's manners during the car accident indicated her psychiatric disorder, which was an effect of being abused, other than her emotional stress, and that can be considered a symptom of her trauma [15]. In this context, besides Silvia's beloved cello, she used her own body as another alternative tool to heal the trauma embedded in her mind.

On another occasion, Silvia ran away from home after she had recovered from injury and had been released from the hospital. This time Silvia, again, used her body as a tool to heal her long-term trauma through trying sexual activity with Toni, a friendly waiter at the game room. Toni became infatuated with Silvia, but she only felt impressed with his gently caring manners. For Silvia, the sexual activity with Toni was not meant to happen just for fulfilling her sex drive or pleasure. She determined to use her own body to indulge in sexual act with this trustful man in order to obliterate sexual sense rooted in her conscience due to the affairs with her father, and to gain new sex experience with a man who was not her father. In the sex scene between Silvia and Toni which the protagonist's body was used as a tool for healing her trauma, the film creator presented the intercourse shot in which Toni clearly penetrated to her genital. The pain on Silvia's unhappy face and her forlorn expression after Toni reached orgasm implied her dissatisfaction with the activity. Due to this sequence, in addition with Silvia's problem on her 
excretory system as stated earlier, it can be assumed that the sexual intercourse between Silvia and her father, which never appeared explicitly on screen, was mostly performed at the back part of her body.

Moreover, in the last part of the film, after Silvia ran away from her father to temporarily stay with Maite and her boyfriend who had a problem on sharing leisure hours at late night with Silvia, she, at this crucial time, used her body as a tool to heal her trauma by having a brief meeting with her father at his apartment and bitterly tempting him to have sex with her on the sofa. The sexual activity between the protagonist and her father in this film sequence, like the other ones throughout the entire film, was presented obscurely to the audiences, and it implied an intercourse which Silvia's father performed to the front part of her body. Silvia meant to turn that meeting to be a chance for her to confront with her father who initially created the agony of great pain which she was drawn into almost her entire life, and she decided at last to drive all sufferings, including himself, away from her life. Silvia, in tears, expressed her bitterness and pain in this crucial sex activity as a healing, and it encouraged her to eradicate him, and her trauma practically. Later, Silvia informed Maite, in a chance of their reconciliations after Maite's trouble with her generous but moody boyfriend, about her unspoken secret by asking Maite if her father ever had Maite sexually abused, and that question, in consequence, gave Silvia more helping hands from her close friend, who never had sex with her father, and also from the related community.

\section{FACE THE FEAR AND ACCEPT IT}

The most essential part in the healing process for the sexual abused which Armendariz suggested to the audiences through this representation lied in the sequence that Dr. Hidalgo advised melancholic Silvia on having her broken soul, which was like a glass fallen on the floor and shattered into little pieces, recovered from being abused by her father whom she both loved and hated. Such feelings made Silvia hurt very much, and gave her a terrible fright. Silvia as a young lady bitterly confessed to her mother, who was appalled on hearing, that her father was her first and only lover, and she had to bear harder pressure when her mother denied the truth and avoided discussion on the issue the same way she had done with little Silvia in the past. Silvia was very confused and got stuck with the most painful fact about her father's role which had great influence on her life: he, who was her most beloved person, was the same man who cold-bloodedly ruined her life. She, again and again, asked herself to find a solution for that terrible fact, only to find herself struggling in vain. Though, later, Silvia stayed apart from him, that painful feelings still haunted her. The situation became worse for Silvia when she met her father by chance on street and was asked to reunite with him. Dr. Hidalgo encouraged Silvia to confront that haunting fact by not attempting to understand it, but by accepting it and letting it go, the same way one should accept a condition of a glass which was too shattered to be mended. This advice from Dr. Hidalgo's counseling process was related to reconstructing Silvia's strong attitude which she was familiar with for years, and it took her not just a little period of time to adjust herself. Encouraging the abused to accept such a painful fact in her or his life, thus, could provide a chance for her or him to stay stronger with it and later to search for some suitable resolutions to relieve it. This method is relevant to what Nancy Venable Raine [16] advised "...denying painful feelings is like swallowing a time bomb."

In the context of similar experiences to Silvia's, being sexually abused by the most intimate person in family creates a haunting trauma to the abused and drives them to bear great sufferings in silence fearfully [17]. In spite of various kinds of treatment, including, as presented in the film, having a counsel with a psychiatrist like Dr. Hidalgo who had comfort talks with the protagonist, lent her some books to help her heal herself on her own, and had her mesmerized, even the painful method initially experimented by Silvia on using her own body as an implement in sexual activities in order to relieve her sufferings, it is very difficult for the abused to erase the stigma solidly sealed within their souls. Hence, making a change on the abused's attitudes is very essential, and the healing process may take a very long period of time.

\section{EMPOWERING GAZE, EMPOWERING SOUL}

Since the beginning until the end of No Tengas Miedo, sequences showing faces of victims of sexual abuses recounting their traumas and sufferings caused by sexual experiences in a group therapy appeared from time to time on screen. Those in the group, various in gender and age, shared the same kind of experience. They were sexually abused since childhood by close and trusted people in their family, neighborhood, or school. Some male group members were even victimized by people of their own sex. To the audiences, those sequences are represented through a character's look about which the audiences would clearly know by the end of the film. Representing those sequences in such a way essentially locates the audiences in the position of observers, who, in the first place, are supposed to feel like those abused victims in order that they could explore each character in the group and learn about their traumas and sufferings, including the causes and effects of their abused conditions. As a person who, in early teenage years, experienced sexual abuse performed by a close relative though not related in blood, I, the author of this paper, consider my experience a mild violence, which affected my body and soul in a low degree, and share those characters' traumas and sufferings with sympathy as a member in the community of the sexual abused represented in this film. Making an observation on such a community allowed me to have my own experience revised, and, along the way, provided me the chance to heal and empower my soul.

In addition, I, as an audience of the film, had a certain chance to explore the life experience of a middle-aged male character in the group who had been sexually abused in his early years, and later, by the result of gradually absorbing the violence in power relation on the abusive acts, became the abuser himself. This discovery led me to a consideration on the stereotypical condition of the child sexual abused as a victim. From the character's perspective and behavior, it was very clear that the sexual abused had a potential to turn 
himself into a person who spread the same kind of violence he had been familiar with since childhood, and would at a certain level enjoy abusing others [18].

In the end, the film thoughtfully revealed it was through Silvia's look which the observation in the therapy group whose members, including Silvia, had experienced sexual abuse since young age were made. Taking participation in the group to share such an experience was another essential part, nearly in the end of the healing process which Dr. Hidalgo brought Silvia to enhance her treatment, after Silvia made change in her attitudes towards traumas and sufferings caused by the abuse. This community, therefore, played the very important role in the healing process, which provided chances for the abused to make them less alienated with their own selves and others, and which potentially encouraged Silvia and other group members to step forward to the status of survivor of being abused. From the activities of group therapy, Silvia, altogether with her abused friends, learned and realized that each group member had traumatic experiences which they, on their own, all knew about and shared with one another. Each member was stigmatized by such an experience, and needed understanding and forgiving basically from herself or himself. In the community, all members took essential parts in witnessing testimonies, sharing traumas and sufferings, and encouraging one another to get through healing. While becoming part of the community, Silvia also learned that her case was just a case of an individual among others who had experienced terrible violence. All of the other community members' traumas partly had roles in healing her soul, and her trauma could partly do the same with theirs.

Powerfully and skillfully, No Tengas Miedo presents the creative gaze as stated above through the eyes of its female protagonist who took part in the community of the sexual abused with the atmosphere of sincerity, which paved ways for the abused to get over the agony of pain to the refined condition on which their stigmas in the past were accepted fundamentally by themselves. The female gaze in the essential sequences of this representation was created so maturely and caringly that it led to the empowerment on both the protagonist's soul and the audiences' souls. Those shots representing female gaze also provides the exploration on life with hope for a chance to carry on, which is conformed by the film's last sequence projecting a medium shot of Silvia in a more relaxed manner after breaking free, in a much higher level, from her father, whom she went to confront at his apartment after an unexpected meeting with him on a street while she was looking for a new apartment during the time she shared her couple life openly with Toni. The chance for such an exploration on the life with hope was also conformed, at the film's end credit, by the melancholic sweet tune of cello, a reminiscent of the protagonist's beautiful talent on music.

\section{CONCLUSION}

As a representation, the Spanish film, No Tengas Miedo, was created so thoughtfully that it possesses a high potential as an empowerment for society. Besides the function in entertaining its audiences, it provides a practical process for healing those who experienced sexual abuse at a young age by their parents or intimate people placing stigmas on them. The essential methods in the process presented by the film creator to heal the abused's souls are facing the fear of traumatic experience, accepting it, and finally letting it go. In the healing process, courage and encouragement are necessary, and the possibility to create them basically depend on the abused herself or himself. Except family members, close friends, or intimate people, experts performing their duties with good care and honesty, like the psychiatrist in the film, play important roles in taking care of the abused, and should have capabilities to provide a sincere community for the abused to take part in a group therapy. Vitally, the community for the sexual abused presented in No Tengas Miedo tends to construct an imagined community for the audiences, especially those with similar experiences to the protagonist, despite differences in ethnicity, culture, or language, to practically heal their traumas on their own. What the audiences can basically share with the protagonist are traumas and sufferings caused by sexual abuse which essentially affects their self agencies.

\section{ACKNOWLEDGMENT}

The author of this paper would like to thank Poom Namvol for his kind help on proofreading and editing grammar and vocabulary usages in some part.

\section{REFERENCES}

[1] No Tengas Miedo (Don't be Afraid), Film (Spanish), Montxo Armendariz, Dir. Oria Films, 2011.

[2] Polisse, Film (French), Maïwenn, Dir. Arte France Cinéma and Mars Films, 2011.

[3] Chued-Gorn-Chim (The Butcher), Film (Thai), Tiwa Moeytaisong, Dir. Pranakorn Films, 2009.

[4] Chuan (Slice), Film (Thai), Kongkiat Komesiri, Dir. Five Star Production, 2009.

[5] S. Hall, "The work of representation," in Representation: Cultural Representations and Signifying Practices, S. Hall, Ed., reprinted, London, Thousand Oaks, New Delhi: SAGE Publications, 2003, pp. $15-26$.

[6] K. Ollier and A. Hobday, Creative Therapy: Adolescents Overcoming Child Sexual Abuse, 1st ed., Camberwell, Melbourne: ACER Press, 2004, ch.1, pp. 12-13.

[7] A. Cattanach, Play Therapy with Abused Children, 2nd ed. London and Philadephia: Jessica Kingsley Publishers, 2008, ch. 1, pp. 24-26.

[8] S. J. Tuscic, G. B. Flander, and D. Mateskovic. (2013). The consequences of childhood abuse. Paediatrics Today. [Online]. 9(1). pp. 24-35. Available: http://www.paediatricstoday.com

[9] M. Hamer, Incest: A New Perspective, Malden, MA: Polity, 2002, part 1, pp. 11-14.

[10] C. Kanjanakul and S. Ruengson, "Wife abuse: a hidden domestic crime," in Reconstrucing the Concept of Women and Health, P. Boonmongkon, N. Sanhajariya and S. Ruengson, Ed., n.p.: Gender Press, 1999, pp. 545-571.

[11] G. S. Venumadhava and H. Y. Prashant. (March 2013). Girl child abuse. Indian Streams Research Journal. [Online]. 3(2). pp. 1-7. Available: http://www.isrj.net

[12] D. J. Schober, S. B. Fawcett, and J. Bernier. (July 2012). The enough abuse campaign: building the movement to prevent child sexual abuse in Massachusetts. Journal of Child Sexual Abuse. [Online]. 21. pp. 456-469. Available: http://dx.doi.org/10.1080/10538712.2012.675423

[13] K. A. Duncan, Healing from the Trauma of Childhood Sexual Abuse: The Journey for Women, 1st Ed. Westport, Connecticut and London: Praeger, 2004, app. A, pp. 192-194.

[14] A. Cattanach, Play Therapy with Abused Children, 2 nd ed. London and Philadephia: Jessica Kingsley Publishers, 2008, ch. 1, pp. 22-24.

[15] A. Cattanach, Play Therapy with Abused Children, 2nd ed. London and Philadephia: Jessica Kingsley Publishers, 2008, ch. 1, pp. 26-28. 
[16] N. V. Raine, "After silence: rape and my journey back," n.p.: n.d., cited in C. McCall, When the Piano Stops: A Memoir of Healing from Sexual Abuse, Berkeley, California: SEAL PRESS, 2009, part 2, p. 191.

[17] M. Troiano. (2011). Child abuse: risks, consequences and interventions. Nurs Clin N Am. [Online]. 46. pp. 413-422. Available: http://www. nursing.theclinics.com DOI:10.1016/j.cnur.2011.08.009

[18] A. Cattanach, Play Therapy with Abused Children, 2nd ed. London and Philadephia: Jessica Kingsley Publishers, 2008, ch. 1, p. 33.

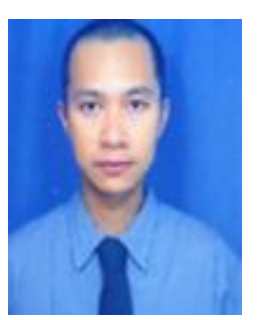

Pogkrong Boon-Long was born in Nakorn Ratchasima, Thailand in 1970. BA $1^{\text {st }}$ class honors, in drama, Thammasat University, Thailand, 1991. $\mathrm{He}$ got MA in women's studies, Thammasat University, 2005 and Ph.D. in literature and comparative literature, Chulalongkorn University, Thailand, 2012. He is currently a full-time lecturer at MA Program in Women, Gender and Sexuality Studies, College of Interdisciplinary Studies,
Thammasat University since 2012. His research interests include gender, sexuality, films and performing arts. For his BA thesis, Dr. Pogkrong staged the theatre-in-the-round production for modern adaptation of Shakespeare's A Midsummer Night's Dream, or Fun-Na-Kuen-Klang-Rue-Du-Ron in Tha version. In the academic year 2005, he received the award from Graduate College, Thammasat University for his outstanding MA thesis, Life with a Badge: Identity and Sexuality of Gay 'Quing' in Sauna M, in the field of women's studies, which essentially inspired him to further his study and write the dissertation entitled Male Homosexual Identity: A Comparative Study of Male Homosexual Characters in Contemporary Tha Autobiography and Drama. In addition, Dr. Pogkrong is the founder of the group of Thai Acting Experts, which has run the activity of appraisal for Thai screen acting since 2003. 